phổi. Điều này có thể do trong nghiên cứu của chúng tôi đối tượng bệnh nhân nghiên cứu là các bệnh nhân nhi nhỏ tuổi (từ sơ sinh đến dưới 15 tuổi) và bị viêm phổi có biến chứng (được chẩn đoán bằng $\mathrm{X}$-quang $\mathrm{CLVT}$ ngực). Trong khi các tác giả trên thì nghiên cứu trên các đối tượng là bệnh nhân bị viêm phổi hoặc nghi ngờ viêm phổi, và có tác giả nghiên cứu trên đối tượng nghiên cứu là là những bệnh nhân lớn tuổi hơn (dưới 18 tuổi). Ở trẻ nhỏ tổ chức phổi chưa hoàn toàn biệt hoá, ít tổ chức đàn hồi, nhiều mach máu và bạch huyết nên dễ gây xẹp phổi (Điều này có thể giải thích tại sao xẹp phổi là biến chứng hay gặp nhất trong các loại biến chứng của viêm phối với tỷ lệ là 62,9\%). Bên cạnh đó, khi có 1 tổn thương ở phổi dễ gây ra rối loạn tuần hoàn phổi, rối loạn quá trình ngoại hô hấp cũng như quá trình trao đổi khí ở phổi. Do những đặc điểm giải phẫu sinh lí bộ phận hô hấp ở trẻ em, nhất là trẻ nhỏ dễ mắc bệnh đường hô hấp, đặc biệt là viêm phổi [6], [7]. Sự khác biệt này có thể dẫn tới sự khác biệt về tỳ lệ của các biến chứng của chúng tôi so với của các tác giả trên.

\section{KẾT LUÂ̂N}

Các dấu hiệu tổn thương viêm phổi cơ bản thường gặp theo thứ tự là dấu hiệu đông đặc, mất dấu hiệu trượt màng phổi và đường $B$ với tỷ lệ lần lượt là 94,3\%, 28,6\% và 20,0\%.
Các dấu hiệu tổn thương của biến chứng viêm phổi hay gặp theo thứ tự là dấu hiệu quad, dấu hiệu signoid và dấu hiệu lung point với tỷ lệ lần lượt là $53,4 \%, 25,7 \%$ và $14,3 \%$.

Xẹp phổi, tràn dịch màng phổi, viêm phổi hoại tử và tràn khí màng phổi là các biến chứng hay gặp của viêm phổi, với tỷ lệ tương ứng là $62,9 \%, 57,1 \%, 40 \%$ và $14,3 \%$.

\section{TÀI LIẸU THAM KHẢO}

1. Brenner DJ, Hall EJJNEJoM (2007), Computed tomography -an increasing source of radiation exposure, 357(22), pp. 2277-2284.

2. Kurian J, Levin $\mathrm{TL}$, Han $B K$, Taragin $B H_{\text {, }}$ Weinstein S (2009), Comparison of ultrasound and CT in the evaluation of pneumonia complicated by parapneumonic effusion in children, AJR Am J Roentgenol, 193(6), pp. 1648-54.

3. Organization WH, Pocket book of hospital care for children: guidelines for the management of common childhood illnesses. 2013: World Health Organization.

4. Rudan I, Boschi-Pinto C, Biloglav Z, Mulholland K, Campbell H (2008), Epidemiology and etiology of childhood pneumonia, Bull World Health Organ, 86(5), pp. 408-16.

5. Xia $Y$, Ying $Y$, Wang $S$, Li W, Shen HJJotd (2016), Effectiveness of lung ultrasonography for diagnosis of pneumonia in adults: a systematic review and meta-analysis, 8(10), pp. 2822.

6. Khánh NG, Bai giảng Nhi khoa tập 1. 2013, NXB Y học: Trường Đại học Y Hà Nội. tr. 390-401.

7. Kim HT, Bài giảng Nhi khoa. 2013, NXB Y hoc Đại học Y dược Thành phố Hồ Chí Minh. tr. 267 -295.

\title{
THAY ĐỔI NỒNG Độ CYTOKINE HUYẾT THANH Ở BÊ̂NH NHÂN VIÊM PHỔI CộNG ĐỒNG DO VI KHUẨN
}

\author{
Lê Thị Diệu Hiền**, Mai Xuân Khẩn**, Tạ Bá Thắng*
}

\section{TÓM TẮT}

Đặt vấn đề: Viêm phổi cộng đồng (VPCĐ) là một trong những bệnh nhiễm trùng đường hô hấp dưới có tỷ lề mắc và tỷ lệ tử vong cao. Nông độ cytokine huyết thanh có vai trò quan trọng trong đánh giá mức độ nặng và tiên lượng bệnh nhân viêm phổi. Mục tiêu: Đánh giá sự thay đổi nồng đô cytokine huyết thanh ở bệnh nhân viêm phổi cộng đồng do vi khuẩn. Đối tướng và phương pháp: Nghiên cứu trên 78 bệnh nhân VPCĐ điều trị tại Bệnh viện Hữu Nghị Việt Tiêp Hải phòng từ tháng 1 năm 2016 đển tháng 12 năm 2019. Các bệnh nhần được cấy khuẩn đờm trước

*Học viện Quân Y

**Đai hoc Y Dước Hải phòng

Chịu trách nhiệm chính: Lê Thị Diệu Hiền

Email: hienbmn612@yahoo.com

Ngày nhận bài: 2.3.2021

Ngày phản biên khoa hoc: 23.4 .2021

Ngày duyệt bài: 4.5.2021 khi dùng kháng sinh. Kết quả và kết luận: Kết quả cấy khuẩn đờm mọc vi khuẩn Gram âm là 62 BN chiếm $79,49 \%$ và Gram dương là 16 BN chiếm $20,51 \%$. Giá tri trung vi các cytokine của nhóm bênh tại ngày 1 và ngày 7 đều cao hơn nhóm chứng và ở ngày 7 thấp hơn ngày 1 . Với 5 vi khuẩn thường gặp cho thây TNF-a, IL-6 và IL-10 tăng chiếm đa số. Nhóm vi khuẩn Gram dương có giá trị IL-6 và IL-10 cao hơn nhóm Gram âm nhưng giá trị TNF-a lại thấp hơn.

Tư khóa: Viêm phối mắc phải cộng đông; Đặc điểm vi khuẩn; Cytokine

\section{SUMMARY}

\section{CHANGES IN SERUM CYTOKINE LEVELS IN PATIENTS WITH COMMUNITY-ACQUIRED BACTERIAL PNEUMONIA}

Background: Community-acquired pneumonia (CAP) is one of the lower respiratory tract infections with high morbidity and mortality. Level of serum cytokine plays an important role in assessing the severity and prognosis of patients with pneumonia. 
Objectives: To evaluate changes in serum cytokine levels in patients with community-acquired bacterial pneumonia. Subjects and methods: Research were conducted among 78 CAP patients treated at Huu Nghị- Viet Tiep Hospital, Haiphong from January 2016 to December 2019. The patients's sputum were cultured before they took antibiotics. Results and conclusions: Results of sputum culture: Gramnegative and Gram-positive bacteria were observerd among 62 patients $(79.49 \%)$ and 16 patients $(20.51 \%)$, respectively. Levels of cytokines at day 1 and day 7 of the CAP group were higher than the one of control group and the level at day 7 was lower than day 1. Level of TNF-a, IL-6 and IL-10 increased among patients with 5 most common bacteria. Compared with Gram-negative bacteria group, the level of IL- 6 and IL-10 in Gram-positive bacteria group were higher, but TNF-a level was lower.

Keywords: Community-acquired pneumonia; Bacterial characteristics; Cytokines

\section{I. ĐĂT VẤN ĐỀ}

Viêm phổi công đồng (VPCĐ) là một trong những bệnh nhiếm trùng đường hô hấp dưới có tỷ lệ mắc và tỷ lệ tử vong cao [3]. Sự đáp ứng viêm trong VPCĐ khác nhau ở mồi cá thể, tùy thuộc vào nguyên nhân gây bệnh và mức độ nặng của bệnh. Các cytokine được sản xuất trong quá trình đáp ứng viêm phụ thuộc vào thời gian mấn cảm với các độc tố của nguyên nhân vi sinh gây bênh. Vai trò của cytokine trong VPCĐ đã được một số nghiên cứu đề cập: Interleukine6 là một yếu tố tiền viêm và Interleukine-10 là một yếu tố kháng viêm được coi là quan trọng nhất trong cơ chế sinh bểnh của VPCĐ. Các cytokine này có liên quan đển mức độ viêm phổi cũng như kết cục điều trị. Tuy nhiên sự biến đổi của cytokine huyết thanh có sự khác nhau theo các thể bệnh nhân, nguyên nhân vì sinh cũng như các thời điểm đánh giá trong các nghiên cứu khác nhau. Mục tiêu của nghiên cứu này là: Đánh giá sự thay đổi nồng độ cytokine huyết thanh ở bệnh nhân viêm phổi cộng đồng do vi khuẩn tại Bệnh viện Hữu Nghị Việt-Tiệp Hải Phòng.

\section{II. ĐỐI TƯỢNG VÀ PHƯƠNG PHÁP NGHIÊN CỨU}

2.1. Đối tượng nghiên cứu. Gồm 78 bệnh nhânVPCĐ điều trị tại Khoa nội hô hấp- Bệnh viện Hữu Nghị Việt Tiệp Hải Phòng từ tháng 1 năm 2017 đến tháng 12 năm 2019.

Tiêu chuẩn lựa chọn bệnh nhân: Các bệnh nhân được chẩn đoán xác định viêm phổi mắc phải cộng đồng theo tiêu chuẩn của Hội lồng ngực Hoa Kì (ATS 2007); nuôi cấy định danh vi khuẩn đờm dương tính; tuổi từ 16 trở iên.

Loại trừ những bệnh nhân có bệnh hô hấp khác kết hợp như lao phổi, giãn phế quản, bênh phổi tắc nghẽn mạn tính, ung thư phổi; các bệnh lý tự miễn.

\subsection{Phương pháp nghiên cứu}

Thiêt kế nghiên cứu: Nghiên cứu mô tả, theo dõi dọc, tiến cứu.

Các bệnh nhân được khám lâm sàng đánh giá triệu chứng của nhiễm trùng, triệu chứng hô hấp và các cơ quan, các bệnh kết hợp, tiền sử dụng kháng sinh, làm các xét nghiệm: cấy khuẩn đờm, xét nghiệm công thức máu, sinh hóa máu, Xquang ngực, nồng độ CRP, PCT huyết thanh, nồng độ các cytokine (TNF-a, IL-6 và IL-10) huyết thanh tại hai thời điểm (khi nhập việnngày 1 và sau 7 ngày điêu trị-ngày 7). Xét nghiệm nồng độ TNF-a, IL-6 và IL-10 huyết thanh theo nguyên lý kỹ thuật hấp phụ miễn dịch vi hạt huỳnh quang (Fluorescence covalent microbead immunosorbent assay-FCMIA). Đánh giá mức độ viêm phổi theo thang điểm CURB-65. Đánh giá thay đổi nồng độ các cytokine huyết thanh so với giá trị tham chiếu ở nhóm người bình thường (bình thường khi bằng giá trị trung vị, tăng khi lớn hơn trung vị ở nhóm người bình thường) và theo 2 thời điểm xét nghiệm. Nhập và xử lý số liệu bằng phần mềm STATA 14.2.

\section{KẾT QUẢ NGHIÊN CứU}

Bảng 3.1: Đặc điểm chung bệnh nhân nghiên cứu

\begin{tabular}{|c|c|}
\hline Các biến số & Giá trị \\
\hline $\begin{array}{l}\text { Nhóm tuối } \\
\leq 65 \text { tuô̂i } \\
>65 \text { tuôii }\end{array}$ & $\begin{array}{l}33(42,3 \%) \\
45(57,7 \%)\end{array}$ \\
\hline $\begin{array}{l}\text { Giới: } \mathbf{n}(\%) \\
\text { Nam } \\
\text { Nữ }\end{array}$ & $\begin{array}{l}51(65,38 \%) \\
27(34,62 \%)\end{array}$ \\
\hline $\begin{array}{l}\text { Bệnh kết hợp: n (\%) } \\
\text { Đái tháo đường } \\
\text { Suy thận mạn } \\
\text { Tăng huyết áp } \\
\text { Đột quy não } \\
\end{array}$ & $\begin{array}{l}12(53,8 \%) \\
3(3,85 \%) \\
8(12,6 \%) \\
3(3,85 \%) \\
\end{array}$ \\
\hline $\begin{array}{l}\text { Tiền sử dùng kháng sinh } \\
\text { trước đó } 3 \text { tháng: n (\%) }\end{array}$ & $11(17,02 \%)$ \\
\hline $\begin{array}{c}\text { Mức độ viêm phối (điếm } \\
\text { CURB-65): n (\%) } \\
<2 \\
\geq 2\end{array}$ & $\begin{array}{l}43(55,1 \%) \\
35(44,9 \%)\end{array}$ \\
\hline $\begin{array}{c}\text { Kết quả cấy khuấn đờm: } \\
\text { Gram }(+) \\
\operatorname{Gram}(-)\end{array}$ & $\begin{array}{l}16(20,5 \%) \\
62(79,5 \%)\end{array}$ \\
\hline
\end{tabular}

BN nghiên cứu có bệnh kèm theo là đái tháo đường chiếm chiếm $15,38 \%$. BN có tiền sử có dùng thuốc kháng sinh tiêm trong thời gian 3 tháng gần đây chiếm $12,82 \%$.

\section{Bảng 3.2. Biến đổi nông độ các cytokine theo thời gian điều trị}




\begin{tabular}{|c|c|c|c|c|}
\hline Cytokine & $\begin{array}{c}\text { Nhóm người } \\
\text { bình thường } \\
n=34(1)\end{array}$ & $\begin{array}{c}\text { Nhóm bệnh } \\
\text { nhân ngày } 1 \\
n=78 \text { (2) }\end{array}$ & $\begin{array}{c}\text { Nhóm bệnh } \\
\text { nhân ngày } 7 \\
n=78 \text { (3) }\end{array}$ & p \\
\hline $\begin{array}{c}\text { TNF-a: } \\
\text {-Trung vị (max-min) } \\
\text {-Bình thường } \\
\text {-Tăng }\end{array}$ & $\begin{array}{c}0,35 \\
0,18-1,00\end{array}$ & $\begin{array}{c}0,76 \\
0,43-1,42 \\
16(20.51 \%) \\
62(79.49 \%)\end{array}$ & $\begin{array}{c}1,01 \\
0,55-2,37 \\
12(15.38 \%) \\
66(84.62 \%)\end{array}$ & $\begin{array}{c}\mathrm{p} 1,2=0,020^{*} \\
\mathrm{p} 2,3=0,107 * * \\
\mathrm{p}^{\mathrm{a}}=0.394\end{array}$ \\
\hline $\begin{array}{c}\text { IL- 6: } \\
\text {-Trung vị (max-min) } \\
\text {-Bình thường } \\
\text {-Tăng }\end{array}$ & $\begin{array}{c}1,11 \\
0,79-1,92\end{array}$ & $\begin{array}{c}2,15 \\
0,79-6,98 \\
26(33.33 \%) \\
52(66.67 \%)\end{array}$ & $\begin{array}{c}1,12 \\
0,70-2,66 \\
38(48.72 \%) \\
40(51.28 \%)\end{array}$ & $\begin{array}{c}\mathrm{p} 1,2=0,022^{*} \\
\mathrm{p} 2,3=0,003^{*} * \\
\mathrm{p}^{\mathrm{a}}=0.046\end{array}$ \\
\hline $\begin{array}{c}\text { IL- 10: } \\
\text {-Trung vị (max-min) } \\
\text {-Bình thường } \\
\text {-Tăng }\end{array}$ & $\begin{array}{c}1,09 \\
0,65-1,63\end{array}$ & $\begin{array}{c}1,18 \\
0,45-2,58 \\
35(44.87 \%) \\
43(55.13 \%)\end{array}$ & $\begin{array}{c}1,11 \\
0,74-1,91 \\
38(48.72 \%) \\
40(51.28 \%)\end{array}$ & $\begin{array}{c}\mathrm{p} 1,2=0,349 * \\
\mathrm{p} 2,3=0,084 * * \\
\mathrm{p}^{\mathrm{a}}=639\end{array}$ \\
\hline
\end{tabular}

* Mann Whitney test; ** Wilcoxon signrank test

Giá trị trung vị các cytokine của nhóm bệnh tại ngày 1 và ngày 7 đều cao hơn nhóm chứng và ở ngày 7 thấp hớn ngày 1 .

Bảng 3.3. Liên quan giữa thay đổi nồng độ các cytokine ngày 1 với kêt quả cây khuẩn đờm

\begin{tabular}{|c|c|c|c|}
\hline & \multicolumn{2}{|c|}{ Kết quả cấy khuấn } & \multirow[b]{2}{*}{$\mathbf{p}$} \\
\hline & Gram (+) $(n=16)$ & Gram (-) (n=62) & \\
\hline \multicolumn{4}{|c|}{ TNF-a } \\
\hline Bình thường & $4(25 \%)$ & $12(19.35 \%)$ & \multirow{2}{*}{$0.618^{*}$} \\
\hline Tăng & $12(75 \%)$ & $50(80.65 \%)$ & \\
\hline Trung vị (max-min) & $0,64(0,36-3,63)$ & $0,76(0,43-1,35)$ & $0,828^{* *}$ \\
\hline \multicolumn{4}{|c|}{ IL-6 } \\
\hline Bình thường & $5(31.25 \%)$ & $21(33.87 \%)$ & \multirow{2}{*}{$0.843 *$} \\
\hline Tăng & $11(68.75 \%)$ & $41(66.33 \%)$ & \\
\hline Trung vị (max-min) & $3,71(0,73-12,85)$ & $1,9(0,88-6,63)$ & $0,647 * *$ \\
\hline \multicolumn{4}{|c|}{ IL-10 } \\
\hline Bình thường & $6(37.50 \%)$ & $29(46.77 \%)$ & \multirow{2}{*}{$0.506 *$} \\
\hline Tăng & $10(62.5 \%)$ & $33(53.23 \%)$ & \\
\hline Trung vị (max-min) & $2,23(0,57-3,87)$ & $1,15(0,41-1,99)$ & $0,141^{* *}$ \\
\hline
\end{tabular}

${ }^{*}$ Chi2 test $* *$ Kruskal-Wallis test

Nồng độ trung bình của 3 cytokine trong huyết thanh ở hai nhóm bệnh nhân có mọc vi khuẩn Gram âm và Gram dương chưa có sự khác biệt.

Bảng 3.4. Liên quan giữa thay đổi nông độ các cytokine ngày 1 với mức độ viêm phổi

\begin{tabular}{|c|c|c|c|}
\hline \multirow{2}{*}{ ge } & \multicolumn{2}{|c|}{ CURB-65 } & \multirow{2}{*}{$\mathbf{P}$} \\
\hline & $<2$ & $\geq 2$ & \\
\hline \multicolumn{4}{|c|}{ TNF-a } \\
\hline Bình thường & $11(68.75 \%)$ & $5(31.25 \%)$ & \multirow{2}{*}{$0.219 *$} \\
\hline Tăng & $32(51.61 \%)$ & $30(48.39 \%)$ & \\
\hline Trung vị (max-min) & $0.71(0.25-1.29)$ & $0.81(0.53-1.45)$ & $0.245^{* *}$ \\
\hline \multicolumn{4}{|c|}{ II-6 } \\
\hline Bình thường & $15(57.69 \%)$ & $11(42.31 \%)$ & \multirow{2}{*}{$0.747 *$} \\
\hline Tăng & $28(53.85 \%)$ & $24(46.15 \%)$ & \\
\hline Trung vị (max-min) & $1.89(0.76-14.79)$ & $2.55(0.96-5.43)$ & $0.912^{* *}$ \\
\hline \multicolumn{4}{|c|}{ IL-10 } \\
\hline Bình thường & $20(57.14 \%)$ & $15(42.86 \%)$ & \multirow{2}{*}{$0.747 *$} \\
\hline Tăng & $23(53.49 \%)$ & $20(46.51 \%)$ & \\
\hline Trung vị (max-min) & $1.15(0.41-1.99)$ & $1.58(0.51-3.22)$ & $0.310 * *$ \\
\hline
\end{tabular}

Nồng độ trung bình của 3 cytokine trong huyết thanh ở hai nhóm bệnh nhân CURB- $65<2$ điếm và CURB- $65 \geq 65$ chưa có sự khác biệt. 
Bảng 3.5. Tương quan giứa nồng độ cytokine ngày 1 với các dâu ấn viêm

\begin{tabular}{|c|c|c|c|c|}
\hline \multirow{2}{*}{ Cytokine } & \multicolumn{2}{|c|}{ CRP } & \multicolumn{2}{c|}{ PCT } \\
\cline { 2 - 5 } & $\mathbf{r}$ & $\mathbf{P *}$ & $\mathbf{r}$ & P* \\
\hline TNF-a & -0.063 & 0.584 & -0.081 & 0.482 \\
\hline Il-6 & 0.048 & 0.677 & 0.027 & 0.812 \\
\hline IL-10 & 0.021 & 0.856 & -0.104 & 0.365 \\
\hline
\end{tabular}

Nhóm vi khuấn Gram dương có giá trị IL-6 và IL-10 cao hơn nhóm Gram âm nhưng giá trị TNF-a lại thấp hơn. Tuy nhiên sự khác biệt chưa có ý nghĩa thống kê với p>0,05.

\section{BÀN LUẦN}

4.1. Đặc điểm chung bệnh nhân nghiên

cứu. Đề tài của chúng tôi nhóm bệnh nhân( $\mathrm{BN}$ ) $\leq 65$ tuổi có 33 bệnh nhân chiếm $42,3 \%$ và nhóm trên 65 tuổi chiếm 57,7\%. Độ tuổi của bệnh nhân trong nghiên cứu của chúng tôi phù hợp với độ tuổi nguy cơ chung của bệnh VPCĐ trên thế giới, tương tự như nghiên cứu của tác giả Trần Ngọc nghiên cứu tại bệnh viện Cần Thơ, nhóm tuổi > 60 tuổi chiếm $80 \%$ [1]. Nghiên cứu của chúng tôi cho thấy, các bệnh nhân bị VPCĐ có thể mắc một số các bệnh lý kèm theo, trong đó cao nhất là tăng huyết áp $(26,92 \%)$, đái tháo đường $(15,38 \%)$, bệnh thận mạn tính là 3,85\%. Có rất nhiêu yếu tố được nhận định là nguy cơ dẫn đến VPCE, trong đó có tình trạng bệnh lý kèm theo. Nghiên cứu tổng hợp trên 29 nghiên cứu khác của Brazil đã chỉ ra, bên canh các yếu tố như giới tính, cân nặng, tiền cằn sử dụng rượu, hút thuốc thì hiện tượng nhiễm trùng đường hô hấp cấp, hoặc các vấn đề bênnh lý về suy giảm chức năng gan, đái tháo đường, ung thư cũng là những yếu tố được xác định thường đi kèm với $\mathrm{VPC}$, đặc biệt là trên nhóm người cao tuổi [5].

Kết quả vi khuẩn trong mẫu đờm của các bệnh nhân trong nghiên cứu này thu được 7 loại vi khuẩn Gram âm và 5 loại vi khuẩn Gram dương, trong tỷ lệ Gram dương chiếm $20.5 \%$ và Gram âm chiếm $79.5 \%$. Kết quả của chúng tôi có sự khác biệt so với các nhận định trước đây trên thế giới về nguyên nhân gây VPCĐ khi các nghiên cứu này cho rằng $S$, pneumoniae là lại vi khuẩn Gram dương chính gây ra bệnh VPCĐ trên toàn thế giới. Ở Châu Âu, gần $35 \%$ (dao động từ $12 \%$ đến $68 \%$ ) trường hợp là do phế cầu khuẩn. Tuy nhiên, kết quả tống hợp của Ashley Rider về VPCĐ lại cho thấy, trên nhóm đối tượng người trưởng thành đang cần chăm sóc y tế thì nhóm vi khuẩn được phát hiện nhiều nhất là Gram âm bao gồm: K. pneumoniae, E.Coli, S. aureus và $P$. aeruginosa [2].

4.2. Thay đổi nồng độ các cytokine. VPCĐ là một trong những nguyên nhân gây tử vong hàng đầu trong các bệnh nhiễm trùng đường hô hấp dưới. Cho đến nay, các cytokine đã được chứng minh có vai trò trong các phản ứng viêm cũng như trong điều chỉnh đáp ứng miển dịch đặc hiệu của cơ thể. Mặc dù đến nay đã có một vài nghiên cứu sử dụng kết quả định lượng nồng độ các cytokine trong huyết thanh bệnh nhân VPCĐ để tiên lượng mức độ nặng của bểnh, chúng tôi xin phép được bàn luận trong khuôn khổ kết quả của đề tài về mối liên quan giữa sự biến đổi nồng độ cytokine huyết thanh với các triệu chứng lâm sàng và cận lâm sàng trong bênh VPCĐ. Tất cả các tế bào ở bất kỳ bô phận nào trong cơ thể đều có khả năng sản xuất ra các cytokine. Các cytokine chủ yếu được tao ra để phản ứng với các kích thích, khi không còn kích thích nữa thì viêc sản xuất cytokine dừng lại. Có nhiều tác nhẩn gây kích thích sản xuất cytokine bao gồm vi rút, vi khuẩn, chất độc... Các tác nhân này tương tác đặc hiệu với các thành phân trên màng tế bào hoăc tế bào chất, từ đó kích hoạt hoạt động và bộc lộ biểu hiện gen cytokine. Bên cạnh đó, nhiêu cytokine cũng có khả năng tự kích thích sản xuất ra chính nó. Từ những năm 1990, các nhà nghiên cứu đã nhận thây vai trò quan trọng của các cytokine tiền viêm trong bệnh lý VPCĐ, đặc biệt là cytokine IL-6, IL-10 và TNF-a, điều này sau đó được nhiều nghiên cứu chứng minh [6].

Nghiên cứu của chúng tôi định lượng nồng độ 3 cytokine TNF-a, IL-6 và IL-10 của nhóm bệnh là đối tượng nghiên cứu và của nhóm chứng là các tình nguyện viên khỏe mạnh. Nồng độ cytokine của nhóm bệnh được lẩy vào hai thời điểm là ngày đầu tiên và ngày thứ 7 sau khi nhâpp viện. Giá trị xét nghiệm cytokine của nhóm chứng được coi là giá trị bình thường giả định để so sánh với giá trị cytokine của nhóm bệnh. Kết quả nghiên cứu cho thấy giá trị nồng độ cytokine của TNF-a, IL- 6 và IL-10 bình thường giả định lần lượt là $0,35 \mathrm{pg} / \mathrm{mL}, 1,11 \mathrm{pg} / \mathrm{mL}$ và 1,09 $\mathrm{pg} / \mathrm{mL}$, tương tự ở nhóm bệnh ngày 1 có kết quả lần lượt là $0,76 \mathrm{pg} / \mathrm{mL}, 2,15 \mathrm{pg} / \mathrm{mL}$ và 1,18 $\mathrm{pg} / \mathrm{mL}$, ngày 7 có kết quả lần lượt là 1,01 $\mathrm{pg} / \mathrm{mL}, 1,12 \mathrm{pg} / \mathrm{mL}$ và $1,11 \mathrm{pg} / \mathrm{mL}$. Có thể thây kết quả nồng độ cytokine ở nhóm bệnh nhân 
nghiên cứu cao hơn bình thường ở cả ngày 1 và ngày 7. Nồng độ cytokine ở ngày 7 có xu hướng giảm hơn so với ngày 1 , sự chênh lệch này thể hiện rõ nhất ở kết quả của IL-6 với p < 0,05 [2].

Bên cạnh xét nghiệm các yếu tố viêm, xét nghiệm vi sinh vật đóng vai trò quan trọng trong việc chẩn đoán nguyên nhân và định hướng điều trị trong VPCĐ. Mỗi loại vi sinh vật đều có sự nhạy cảm với các loại kháng sinh khác nhau. Nếu nguyên nhân VPCĐ được khoanh vùng hoặc xác định càng sớm thì việc lựa chọn kháng sinh ban đầu càng chính xác bởi cần có một khoảng thời gian từ khi có kết quả xét nghiệm vi sinh vật đến khi có kết quả kháng sinh đồ. Từ đó tăng khả năng điều trị thành công, rút ngắn thời gian điều trị và tiết kiệm chi phí cho người bệnh. Nguyên nhân vi khuẩn gặp trong nghiên cứu của chúng tôi gồm có $K$. pneumonia, P.aeruginosa, A. baumannii, Streptococcus sp, E. coli. Từ kết quả nghiên cứu, chúng tôi đặt ra giả thuyêt rằng nếu kết hợp kết quả sớm của các cytokine cùng với các triệu chứng trên lâm sàng và các xét nghiệm cận lâm sàng khác, chúng ta có thể khoanh vùng nguyên nhân trước khi có kết quả nuôi cấy vi khuẩn. Một khi xác định được nguyên nhân, việc lựa chọn kháng sinh chính xác cho người bệnh có thể thực hiện ngay từ ngày đâuu nhập viện thay vì sử dụng kháng sinh phổ rộng. Từ đó góp phần làm giảm nguy cơ kháng thuốc của vi khuẩn, nhất là trong thời điểm rất nhiêuu loại vi khuẩn kháng thuốc như hiện nay [5].

Nhóm tác giả Rosario Menendez và cộng sự nghiên cứu trên 658 bệnh nhân VPCĐ thông qua đánh giá các chỉ số cytokine viêm, chỉ số procalcitonin $(\mathrm{PCT})$ và $\mathrm{CRP}$ nhằm tìm ra giá trị chẩn đoán nguyên nhân. Kết quả nghiên cứu cho thấy giá trị trung bình thấp của các chỉ số CRP, PCT, TNF-a và IL-6 gặp ở nhóm bệnh nhân VPCĐ không rõ nguyên nhân, ngược lại các chỉ số này tăng cao ở nhóm bệnh nhân VPCĐ có nguyên nhân. Tăng cytokine có vẻ như đặc hiệu với các nguyên nhân khác nhau, điều này được làm sàng tỏ hơn trong nghiên cứu của nhóm tác giả này. Với những bệnh nhân VPCĐ nhiễm khuẩn không điển hình có tăng PCT và IL-6, nhóm bệnh nhân VPCĐ do Enterobacteriacea có tăng IL-8, S. pneumonia có tăng $\mathrm{PCT}$ và Legionella pneumophila có tăng CRP và TNF-a [7]. Nghiên cứu này cho thấy tác nhân gây bệnh khác nhau gây ra những phản ứng khác nhau của cơ thể ở bệnh nhân VPCĐ. Các tác giả cũng cho rằng việc định lượng các nhóm cytokine và yếu tố viêm phần nào giúp các bác sỹ lâm sàng định hướng tới nguyên nhân gây bệnh và có thể sớm đưa ra chiến lược điều trị phù hợp khi việc tìm ra nguyên nhân gây VPCĐ chưa được tiến hành hoặc trong thời gian chờ đợi kết quả vi sinh. Qua đây cũng thấy sự cần thiết của việc xác định độ đặc hiệu, độ nhạy, giá trị chẩn đoán dương tính và giá trị chẩn đoán âm tính của nhóm các cytokine khác nhau ở bệnh nhân VPCĐ, nhằm phục vụ việc định hướng chẩn đoán nguyên nhân và định hướng chiến lược điều trị [7].

\section{KẾT LUÂ̂N}

Bệnh kèm theo là đái tháo đường chiếm chiếm 15,38\%. Tiền sử có dùng thuốc kháng sinh tiêm trong thời gian 3 tháng gân đây chiếm $12,82 \%$. Kết quả cấy khuẩn đờm mọc vi khuẩn Gram âm là 62 BN chiếm 79,49\% và Gram dương là 16 BN chiếm 20,51 \%. Giá trị trung vị các cytokine của nhóm bệnh tại ngày 1 và ngày 7 đều cao hơn nhóm chứng và ở ngày 7 thấp hơn ngày 1 . Sự khác biệt TNF- a của nhóm bệnh ngày 1 so với nhóm chứng có ý nghĩa thống kê $p<0,05$. Nhóm vi khuẩn Gram dương có giá trị IL-6 và IL-10 cao hơn nhóm Gram âm nhưng giá trị TNF-a lại thấp hơn.

\section{TÀI LIẸU THAM KHẢO}

1. Trân Ngọc. (2018). Phân tích tình hình sử dụng kháng sinh trong điều trị nhiễm khuẩn bệnh viện do vi khuẩn Gram âm tại khoa Hồi sức tích cựcchống độc, bệnh viện đa khoa Tây Ninh, Luận văn thạc sỹ, Trường Đại học Dược Hà Nội.

2. Bradley.W, Frazee Ashley.C and Rider.T. (2018). Community-Acquired Pneumonia. Emerg Med Clin North Am, 36(4):665-683.

3. J.Marrie and M. File. (2010). Burden of community-acquired pneumonia in North American adults. Postgrad Med, 122(2):130-141.

4. José Miguel, Sahuquillo-Arce, Rosario Menéndez et al. (2012). Cytokine Activation Patterns and Biomarkers Are Influenced by Microorganisms in Community-Acquired Pneumonia. CHEST,141:137-145.

5. Mateu Serra-Prat, Jordi Almirall, Ignasi Bolíbar, et al. (2017). A Systematic Review of Observational Studies. Respiration, 94(3):299-311.

6. R Coakley, P Glynn and I Kilgallen. (1999). Circulating interleukin 6 and interleukin 10 in community acquired pneumonia. Thorax ,54:51-55.

7. Torres A, Welte $\mathbf{T}$ and Nathwani D. (2012). Clinical and economic burden of community acquired pneumonia among adults in Europe. Thorax, 67:71-91. 